\title{
AN ANALYSIS OF MUNICIPAL INDEBTEDNESS
}

\author{
[Analýza municipální zadluženosti] \\ Veronika Linhartová ${ }^{1}$, Ladislav Němeček ${ }^{2}$ \\ ${ }^{1}$ University of Pardubice, Faculty of Economics and Administration, Studentská 95, 53210 Pardubice \\ Email:veronika.linhartova@upce.cz \\ ${ }^{2}$ University of Pardubice, Faculty of Economics and Administration, Studentská 95, 53210 Pardubice \\ Email:ladislav.nemecek@seznam.cz
}

\begin{abstract}
Municipal indebtedness has become a much debated issue in recent years. This paper analyzes debt development and structure for all the municipalities in the Czech Republic for the years 2001-2014 and examines the indebtedness of a selected sample of municipalities. The paper also evaluates the tools currently available to regulate municipal indebtedness. The methods and procedures used by the authors mainly involve research in professional literature and the analysis of available data on municipal indebtedness. The analysis was concerned primarily with municipalities that have been assessed in recent years as municipalities with a higher rate of economic risk by the Municipal Financial Management Monitoring system performed by the Ministry of Finance of the Czech Republic. The completed analysis suggests that municipal indebtedness is not high when compared to the public debt of the Czech Republic. Only a few municipalities are dealing with indebtedness (or over-indebtedness). Large cities are capable of fulfilling their financial obligations.
\end{abstract}

Keywords: debt regulation, municipal budget, municipal debt analysis, municipal indebtedness, municipality.

JEL classification: H61, H62, H68

Doručeno redakci: 23.11.2015; Recenzováno: 25.11.2015; 5.1.2016; Schváleno k publikování: 23.3.2016

\section{Introduction}

Municipal indebtedness has recently become a much debated issue, with the ever-growing public debt being at the center of attention. Public debt includes all the elements of general government debt. The public debt of the Czech Republic consists of the debt owed by the central government (i.e., sovereign debt); the debt owed by self-governing territorial units, i.e., municipalities and regions; and the debt owed by parafiscal funds (e.g., the Health Insurance Fund) (Dvořák, 2008). However, it would be wrong to omit municipal budget debts when considering the ever-growing public debt.

Municipal indebtedness may be due to several causes, one of them being borrowing financial resources or receiving repayable financial support. Municipalities obtain financial resources from banks or private businesses. Indebtedness may also arise from the return of subsidies worth millions or billions of CZK in the event that a municipality fails to meet the conditions linked to the receipt of a subsidy. Total municipal indebtedness consists of bank loans, issued municipal bonds, repayable financial support that has been received, and other debts including loans from the state budget and state fund budgets. Monitoring and evaluating municipal indebtedness by the Ministry of Finance of the Czech Republic is one of the methods of indirect regulation. More than half of the municipalities in the Czech Republic are facing the issue of indebtedness. The burden of the largest debts falls mainly on large cities. 
The intention of this paper is to analyze the indebtedness of Czech municipalities between the years 2001-2014 and to examine the indebtedness of selected municipalities. The indebtedness regulation tools that are currently available will also be considered.

\section{The Theoretical Background of Municipal Indebtedness}

At the end of each financial year, municipalities report a balanced (revenues equal expenditures), surplus (revenues exceed expenditures), or deficit (expenditures exceed revenues) performance. As a result, financial management is found to be positive, i.e., good, or negative, i.e., signaling potential problems for a certain municipality (e.g., excessive borrowing). The quality of financial management can be assessed according to budget structure, i.e., 8 budgetary classes of financing. The financing class expresses the method of financing revenues and expenditures. This method depicts the receipt of repayable financial support and expenditures for repaying previously received loans and issued bonds or the return on temporarily available funds. Financing is used to determine what sources were used to cover deficits or how a budget surplus was handled. Financing can thus reveal a municipal budget balance, i.e., revenues - expenditures $=(+)$ surplus or $(-)$ deficit $=(-)$ or $(+)$ financing. Therefore, a budget balance is balanced with so-called financing operations. The financing of a budget deficit is marked with a plus sign, which expresses a decrease in financial resources (the current account or cash) or an increase in borrowed funds. On the other hand, the financing of a surplus budget is marked with a minus sign, i.e., the repayment of debt or the provision of municipal loans and financial investments (purchase of securities) (Dafflon, 2002). Over the long-term, a balanced budget represents a municipality's good financial management. Unlike deficit, surplus is considered desirable. Surplus can be deemed positive, for instance, when a municipality is saving up for future investments or when revenues from deposited funds are higher than inflation and a loan is either unavailable or too expensive (Kameníčková, 2014).

\subsection{Regulation of municipal indebtedness in the Czech Republic}

If the municipality's budget does not provide enough non-repayable financial support to cover needs, it is possible to replace non-repayable financial support with repayable support. Repayable revenues include bank loans, issues of municipal bonds and repayable loans, and support from other economic entities, including loans from the state budget. Czech municipalities rely mainly on loans, which tend to be more available than revenues from the issue of bonds. If a loan is granted, a contractual relationship between a municipality and a bank is created. Short-term loans (bridging loans, overdrafts) are usually used to cover common expenditures in order to bridge a time discrepancy between budget revenues and expenditures. Medium-term and long-term loans should be used to finance investments and capital expenditures. When a municipality receives a loan, it must give a guarantee. Municipalities use their future budget revenues or assets as collateral. It is essential that municipality representatives realize the connection between repayable funds and their interest burdens. Compared to loans, issuing municipal bonds is subject to high fees, which are usually higher when a small issue is made. Bonds are issued mainly by large cities (Ang et al., 2013). At the end of 2013, issues of municipal bonds were reported by the cities of Prague, Ostrava, and Liberec. To finance their investments, municipalities can also use municipal leasing (financial or operative leasing). Municipalities use the tangible assets of the leasing company on the basis of a leasing contract. The amount of leasing represents the municipal budget expenditures. Municipalities can also use bills of exchange to fulfill their financial obligations after a certain lapse of time (Peková, 2011). 
At present, municipalities can easily access all financial markets. They can borrow funds for any type of purpose from any financial institution, subject to any terms and conditions, time periods, or interest rates. The powers of the authorities when making decisions about property-related actions and the municipality's financial management are specified in Act No. 128/2000 Coll., the Municipalities Act, as annotated. According to constitutional law, the property rights of all owners have the same content, which is why no other legal regulations deal with the regulation of property rights, e.g., by stipulating a rate of indebtedness (Provazníková, 2009). Section 38 of the Municipality Act exhaustively specifies when a municipality can take the role of a guarantor. The approval of the issuance of municipal bonds by the Ministry of Finance can be considered another form of indebtedness regulation. Pursuant to Act No. 190/2004 Coll., on bonds, a municipality must apply for the approval of the Ministry of Finance to issue bonds. Act No. 250/2000 Coll., on the budgetary rules applicable to territorial budgets, contains provisions that contribute to the prevention of excessive debts; an annual budget is compiled according to a mandatory budget forecast. As a rule, a balanced budget is drawn up. However, a deficit budget can be approved if there is documentation of the way the proposed deficit is to be covered (resources from previous years, a credit agreement, etc.). The deficit must be paid off (using the resources from previous years or repayable resources that are payable in the future). Another form of possible regulation is the system of financial monitoring within the public administration. Pursuant to Act No. 320/2001 Coll., about financial monitoring within the public administration and about changes to certain laws, municipalities are obliged to establish a comprehensive system of financial monitoring to ensure that their management as well as the management of their organizational units and public-benefit organizations are monitored. The Financial Control Act does not apply to reviewing the financial management of self-governing territorial units. Instead, this type of financial management is subject to special legislation given in Act No. 420/2004 Coll., on reviewing the financial management of self-governing territorial units and voluntary associations of municipalities. This reviewing process concerns data such as the annual management of the municipality, which is part of the final account; the disposal and handling of municipal property; and the awarding and execution of public procurements. In the event that a municipal council resigns from office due to municipal indebtedness, there is the institution of the municipal administrators. However, the municipal administrator is not capable of relieving the municipality from its debt, as he/she merely governs the municipality until a new council is elected. Primarily, the administrator ensures that the municipality functions properly and its financial management is in order. He/she cannot enter into credit agreements or apply for subsidies. Between 2004 and 2008, the Ministry of Finance monitored municipal indebtedness by means of a debt services indicator. The municipalities that violated this indicator (i.e., the $30 \%$ limit) were sent a letter by the Finance Minister in which the municipalities were required not to exceed the set limit in the subsequent year. In 2008, this indicator was replaced with the aforementioned system, Municipal Financial Management Monitoring. The Ministry of Finance uses this monitoring system to annually calculate SIMU, a more complex evaluation of municipal management (Provazníková, 2009).

\subsection{Municipal indebtedness regulation in selected European countries}

In most European countries, various mechanisms are used to avoid the situation where a municipality becomes insolvent or help a presently insolvent municipality establish an emergency budget. Mechanisms strictly regulating loans to municipalities are set up in some countries in order to avoid a situation where a municipality is unable to meet its obligations. In European countries, the following mechanisms can be found (Dafflon, 2002): 
- For example, local authorities in Germany are limited by strict conditions relating to borrowing financial resources. A loan may be granted only for government investment expenditure charged to a separate capital account and, moreover, only in the case where the government has exhausted all other sources of income. To provide a loan, the state gives permission after a strict review of management autonomy and determining that accepting the loan does not jeopardize the fulfillment of the local government's obligations.

- Each year, the UK government determines the maximum amount of funds that municipalities can borrow; the level of capital expenditures is also regulated.

- In Denmark, the municipality may borrow only for projects that generate profits to repay the loan. Expenditures can be financed only from income earned in a given year. The budget of the municipality must be balanced when it is composed.

- In the Slovak Republic, indebtedness has been dealt with using a so-called "curative regime and forced administration." The municipality is obliged to introduce a recovery mode if the total amount of its overdue commitments exceeds $15 \%$ of the actual current revenues of the previous financial year and if the municipality did not pay an established fee within 60 days after its due date. The forced administration has far greater powers than the municipal administrator in the Czech Republic.

- In Serbia, Croatia, and Slovenia, there is very strict regulation of municipal indebtedness. For projects that are financed by a loan, a state guarantee is needed.

- In France and Germany, there is a specialized institution dedicated to providing loans to municipalities under better conditions than those on the market, but only for projects that are associated with very little risk.

In some European countries, it is possible for a local government to borrow funds via the capital market. In certain countries, this needs the approval of the Ministry of Finance (alternatively, the Ministry of Local Government). Monitoring local government indebtedness in individual countries is generally governed by the Act.

\section{Methods Used}

The methods and procedures used by the authors mainly involve research in professional literature and the analysis of data provided by the Automated Budget Information System (ARIS) and MONITOR, a specialized information portal. The data are publicly accessible on the website of the Ministry of Finance of the Czech Republic (hereinafter referred to as 'the Ministry of Finance'). The data were first processed and then analyzed.

The selected municipalities were analyzed by means of certain indicators used in the System of Informative and Monitoring Indicators (SIMU) that is compiled annually by the Ministry of Finance. The primary objective of monitoring municipal financial management is not to evaluate the rate of debt of individual municipalities but to assess their economic standing. In particular, the following indicators were chosen: liabilities, the ratio of liabilities to total assets (in \%), and standard liquidity (the ratio of current assets to current liabilities). The municipalities whose standard liquidity indicator falls within the $\langle 0 ; 1\rangle$ interval and whose ratio of liabilities to total assets is simultaneously higher than $25 \%$ (inclusive) are sent a letter by the minister of finance.

The total indebtedness indicator follows the SIMU methodology compiled by the Ministry of Finance (2008). According to this methodology, debt consists of loans and municipal bonds, repayable financial support received, and other debts. Total debt can be determined by adding up the relevant synthetic accounts from a municipality's balance sheet. Because this type of 
debt calculation includes only some of a municipality's liabilities, the analysis of the selected municipalities presented here analyzes the total liabilities of those municipalities.

\section{The Development and Structure of Debt in the Czech Republic}

Neither the Ministry of Finance nor any other body is able to influence potential municipal budget deficits. It is solely up to the municipal councils to propose their budget deficit. However, there are laws regulating the financial management of self-governing territorial units. These laws are aimed at reducing excessive indebtedness. These laws will be described later in this text. First, let us present the structure of municipal debts for the years 2000 2014.

Since 1993, municipalities have been cooperating frequently with capital markets. Mainly, their municipal development needs and attempts to fix long-neglected infrastructure have been so financially demanding that standard revenues have not been able to cover them. A relatively high increase in debts was seen in 1993 and in the subsequent years. In the first years, debt was seen mainly in smaller municipalities. Later, larger cities, which began to issue municipal bonds, began to contribute to the total municipal debt. During 1999-2000, the rate of debt slowed down, thanks to extraordinary revenues from the sale of municipalities' property rights held in energy and gas companies (Provazníková, 2009). For summary information on municipal indebtedness during the years 2001-2014, see Table 1. At the end of 2014, municipalities (including municipal organizations partially funded from the state budget) reported total debts of CZK 88.9 billion, i.e., a decrease of 3.6\%, or CZK 3.3 billion, compared to 2013. The debts consisted mainly of bank loans, whose value continues to grow. Compared with 2001, this is an increase of CZK 45.1 billion. The debts also include issued municipal bonds, repayable financial support received, and other loans, including loans from the state budget and state funds. Over the long-term, the debt structure has been dominated by loans, as previously stated. In 2014, these represented $76.2 \%$ of all the debts. Compared to 2013 , the ratio of issued municipal bonds was reduced by $21.3 \%$ and comprised $13.3 \%$ of the total debts in 2014.

Table 1: Summary Information on Municipal Indebtedness for 2000-2014 (in CZK billions)

\begin{tabular}{|c|c|c|c|c|c|}
\hline Year & Loans & Municipal bonds & \multicolumn{2}{|c|}{$\begin{array}{c}\text { Repayable financial support } \\
\text { received and other debts }\end{array}$} & Total \\
\hline $\mathbf{2 0 0 1}$ & 22.6 & 22.6 & 13.3 & 12.4 & 48.3 \\
\hline $\mathbf{2 0 0 2}$ & 27.3 & 27.3 & 15.9 & 12.6 & 55.8 \\
\hline $\mathbf{2 0 0 3}$ & 35.2 & 35.2 & 21.7 & 13.5 & 70.4 \\
\hline $\mathbf{2 0 0 4}$ & 38.5 & 38.5 & 23.9 & 12.4 & 74.8 \\
\hline $\mathbf{2 0 0 5}$ & 43.7 & 43.7 & 23.5 & 11.8 & 79.0 \\
\hline $\mathbf{2 0 0 6}$ & 47.1 & 47.1 & 22.9 & 10.9 & 80.9 \\
\hline $\mathbf{2 0 0 7}$ & 46.7 & 46.7 & 22.6 & 9.9 & 79.2 \\
\hline $\mathbf{2 0 0 8}$ & 47.4 & 47.4 & 22.7 & 10.0 & 80.1 \\
\hline $\mathbf{2 0 0 9}$ & 55.8 & 55.8 & 14.7 & 10.1 & 80.6 \\
\hline $\mathbf{2 0 1 0}$ & 59.9 & 59.9 & 15.8 & 7.6 & 83.3 \\
\hline $\mathbf{2 0 1 1}$ & 60.9 & 60.9 & 14.0 & 7.5 & 82.4 \\
\hline $\mathbf{2 0 1 2}$ & 68.3 & 68.3 & 13.8 & 7.9 & 90.0 \\
\hline $\mathbf{2 0 1 3}$ & 68.8 & 68.8 & 15.0 & 8.4 & 92.2 \\
\hline $\mathbf{2 0 1 4}$ & 67.7 & 67.7 & 11.8 & 9.4 & 88.9 \\
\hline
\end{tabular}

Source: The Ministry of Finance of the Czech Republic: Státní závěrečné účty 2001 - 2013 [online] [cit. 15. January 2016]. Accessible at: www.mfcr.cz/cs/vyhledavani?q=st\%C3\%A1tn\%C3\%AD+z\%C3\%A1v\% C4\%9Bre\%C4\%8Dn\%C3\%A9+\%C3\%BA\%C4\%8Dty; Ministry of Finance of the Czech Republic: Zadluženost územních rozpočtů v letech 2014, 2013, 2012, 2011, 2010, 2009, 2008, 2007 [online] [cit. 15. January 2016]. Accessible at: www.mfcr.cz/cs/verejny-sektor/monitoring/zadluzenost-uzemnich-rozpoctu 
Table 2 (below) shows the year-on-year rate of municipal indebtedness.

Table 2: The Year-on-Year Rate of Municipal Indebtedness for 2001- 2014 (in \%)

\begin{tabular}{|l|c|c|c|c|c|c|c|}
\hline Year & $\mathbf{2 0 0 1}$ & $\mathbf{2 0 0 2}$ & $\mathbf{2 0 0 3}$ & $\mathbf{2 0 0 4}$ & $\mathbf{2 0 0 5}$ & $\mathbf{2 0 0 6}$ & $\mathbf{2 0 0 7}$ \\
\hline Year-on-year rate (in \%) & $X$ & 15.53 & 26.16 & 6.25 & 5.61 & 2.41 & -2.10 \\
\hline Year & $\mathbf{2 0 0 8}$ & $\mathbf{2 0 0 9}$ & $\mathbf{2 0 1 0}$ & $\mathbf{2 0 1 1}$ & $\mathbf{2 0 1 2}$ & $\mathbf{2 0 1 3}$ & $\mathbf{2 0 1 4}$ \\
\hline Year-on-year rate (in \%) & 1.14 & 0.62 & 3.35 & -1.08 & 9.22 & 2.44 & -3.58 \\
\hline
\end{tabular}

Source: Authors' own calculations based on data of the Ministry of Finance of the Czech Republic: Státní závěrečné účty $2001-2013$ [online] [cit. 15. January 2016]. Accessible at: www.mfcr.cz/cs/ vyhledavani?q=st\%C3\%A1tn\%C3\%AD+z\%C3\%A1v\%C4\%9Bre\%C4\%8Dn\%C3\%A9+\%C3\%BA\%C4\%8Dty and the Ministry of Finance of the Czech Republic: Zadluženost územních rozpočtů v letech 2014, 2013, 2012, 2011, 2010, 2009, 2008, 2007 [online] [cit. 15. January 2016]. Accessible at: www.mfcr.cz/cs/verejnysektor/monitoring/zadluzenost-uzemnich-rozpoctu

Table 2 clearly shows that debt reduction was observed in 2007, 2011, and 2014 during the period monitored. For the first time since 1993, municipalities reported a year-on-year debt decrease of $2.1 \%$, or CZK 1.7 billion, in 2007. This reduction can be attributed to the postponement of several capital expenditures, which was necessitated to a great extent by postponed deadlines for the approval of operational programs co-financed from the EU budget and postponing the implementation of numerous projects (Provazníková, 2009).

It follows from Table 1 that municipal indebtedness during the years 2005-2011 was stagnant and averaged at CZK 80 billion. Compared with 2011, debt in 2012 increased by CZK 7.6 billion (9.2\%) to CZK 90 billion. Loans increased by CZK 7.4 billion. The loans received by municipalities in the preceding years were used primarily for reconstructing and building technical infrastructure, re-financing investment projects co-financed by EU funds, and regenerating and building residential housing. Furthermore, municipalities used loans to finance reconstruction projects, thermal insulation, and additions to school buildings and facilities as well as athletic and other facilities. The capital city of Prague and certain other chartered towns received loans from the European Investment Bank to improve municipal infrastructure. Most of these loans have a lower interest rate and a very long repayment period. Recently, municipalities have been granted most of their loans by the following banks: Česká spořitelna, a. s.; Komerční banka, a. s.; and Československá obchodní banka, a. s. Approximately half of these loans were provided without requiring any collateral from the municipalities.

The four largest Czech cities (Prague, Brno, Plzeň, and Ostrava) have recently contributed substantially to total municipal indebtedness. Their debts, including their percentage of total indebtedness, are presented in Table 3. 
Table 3: The Development of the Debt of the 4 Largest Cities Compared to Total Municipal Indebtedness for 2001-2014 (in CZK billions)

\begin{tabular}{|c|c|c|c|c|}
\hline Year & $\begin{array}{c}\text { Total municipal } \\
\text { indebtedness in the } \\
\text { Czech Republic }\end{array}$ & $\begin{array}{c}\text { Debt owed by the } \\
\text { 4 largest cities }\end{array}$ & $\begin{array}{c}\text { Debt without the 4 } \\
\text { largest cities }\end{array}$ & $\begin{array}{c}\text { The 4 largest cities' } \\
\text { rate (in \%) of total } \\
\text { indebtedness }\end{array}$ \\
\hline $\mathbf{2 0 0 1}$ & 48.1 & 24.2 & 23.9 & 50.1 \\
\hline $\mathbf{2 0 0 2}$ & 55.8 & 29.6 & 26.2 & 53.0 \\
\hline $\mathbf{2 0 0 3}$ & 70.4 & 42.4 & 28.0 & 60.2 \\
\hline $\mathbf{2 0 0 4}$ & 74.8 & 45.9 & 28.9 & 61.4 \\
\hline $\mathbf{2 0 0 5}$ & 79.0 & 48.4 & 30.6 & 61.3 \\
\hline $\mathbf{2 0 0 6}$ & 80.9 & 47.4 & 33.5 & 58.6 \\
\hline $\mathbf{2 0 0 7}$ & 79.2 & 46.3 & 32.9 & 58.5 \\
\hline $\mathbf{2 0 0 8}$ & 80.1 & 45.8 & 34.3 & 57.2 \\
\hline $\mathbf{2 0 0 9}$ & 80.6 & 39.3 & 41.3 & 48.8 \\
\hline $\mathbf{2 0 1 0}$ & 83.3 & 40.1 & 43.2 & 48.1 \\
\hline $\mathbf{2 0 1 1}$ & 82.4 & 38.4 & 44.0 & 46.6 \\
\hline $\mathbf{2 0 1 2}$ & 90.0 & 45.5 & 44.5 & 50.6 \\
\hline $\mathbf{2 0 1 3}$ & 92.2 & 49.2 & 43.0 & 53.4 \\
\hline $\mathbf{2 0 1 4}$ & 88.9 & 45.3 & 43.6 & 51.0 \\
\hline
\end{tabular}

Source: Authors' own calculations based on data from the Ministry of Finance of the Czech Republic: Zadluženost územních rozpočtů v letech 2014, 2013, 2012, 2011, 2010, 2009, 2008, 2007 [online] [cit. 15. January 2016]. Accessible at: www.mfcr.cz/cs/verejny-sektor/monitoring/zadluzenost-uzemnich-rozpoctu

During the period monitored, the 4 largest cities' rate of total municipal indebtedness averaged at 54.2\%. Between 2004 - 2011, their percentage continued to drop (from 61.4\% in 2004 to $46.6 \%$ in 2011). However, it rose to 50.6\% in 2012, where it remained in 2013. In 2014, it began to fall again and finally stabilized at $51.0 \%$. Compared to total public debt, municipal indebtedness is not high overall. Calculations revealed that municipal indebtedness in 2013 was $5.01 \%$ of the public debt and $2.26 \%$ of GDP (Czech Statistical Office, 2015). However, it is mainly the debt owed by small municipalities that presents a problem. The number of small municipalities in debt is not high, but, when a small municipality reports debt, their debts are huge. The budget revenues of small municipalities are markedly lower than those of large cities. As a result, smaller municipalities find it more difficult to repay their obligations. Large cities run larger volumes of debts, yet they are exposed to smaller risks related to debt repayment, thanks to their large budgets (Kameníčková, 2011).

\section{Analysis of selected municipalities}

The analysis below focused primarily on municipalities that were recently evaluated as being municipalities with a higher financial management risk by the Ministry of Finance's Financial Municipality Management Monitoring. The municipalities chosen for analysis are shown in Table 4 along with their basic characteristics. 
Table 4: Basic Information on the Selected Sample of Municipalities

\begin{tabular}{|l|c|c|c|c|c|}
\hline Municipality & Prameny & Bublava & Turovice & Pohled & Měňany \\
\hline Population & 112 & 374 & 222 & 773 & 293 \\
\hline District & Cheb & Sokolov & Přerov & Havlíčkův Brod & Beroun \\
\hline Region & Karlovy Vary & Karlovy Vary & Olomouc & Vysočina/Highland & Central Bohemia \\
\hline Cadastral area (ha) & 2461 & 615 & 363 & 1068 & 815 \\
\hline $\begin{array}{l}\text { Altitude (meters } \\
\text { above sea level) }\end{array}$ & 725 & 735 & 238 & 437 & 318 \\
\hline $\begin{array}{l}\text { Number of economic } \\
\text { entities }\end{array}$ & 49 & 122 & 40 & 126 & 51 \\
\hline
\end{tabular}

Source: Authors' own calculations based on the Czech Statistical Office: Ekonomické subjekty podle právní formy [online] [cit. 27. January 2016]. Accessible at: vdb.czso.cz/vdbvo/tabparam.jsp? page $=$ strom $\&$ vo=tabulka\&cislotab=ORG9020UC\&voa=tabulka\&go_zobraz $=1 \&$ childsel $0=5$

The following indicators were selected to analyze the municipal indebtedness of the above municipalities: total liabilities, standard liquidity, and the rate of liabilities to total assets. The analysis used total liabilities (not indebtedness), because the method for calculating indebtedness used by the Ministry of Finance includes only selected elements of indebtedness. According to the authors, this does not have the necessary predictive value required by this analysis.

The municipality of Prameny encountered financial problems, because it failed to implement its plan to build a mineral water bottling plant. According to the then-mayor, Václav Brenner, the municipality invested approx. CZK 30 million of its own funds into 17 exploration wells (each cost approx. CZK 1 million.), licenses, and land purchase. Prameny found an investor and secured all the required approvals. Eventually, the investor abandoned the construction project because of the negative attitude environmentalists took towards the municipality's plan (the Union of Towns and Municipalities of the Czech Republic, 2014). At the end of 2013, the municipality's liabilities were as much as CZK 90 million, including the original investment of CZK 30 million plus sanctions. At present, the municipality of Prameny is one of the most indebted municipalities in the Czech Republic (the Ministry of Finance of the Czech Republic, 2010, 2015).

The municipality of Bublava contracted debts in connection with building a multipurpose facility (aqua park), which was financed mainly from the state budget. The municipality received subsidies from the Ministry of Finance and from the Ministry of Youth and Physical Education totaling CZK 57 million. Because the contractor for the construction work, IPS a. s. Praha (today Skanska), withdrew from the contract, the municipality failed to meet the aqua park completion deadline. The Ministry of Finance issued a decision for violation of budgetary discipline owing to the unauthorized use of state funds. The Revenue Authority in Sokolov ordered the municipality to return the funds plus a penalty, i.e., a total amount of CZK 73,308,040. In 2004, the Finance Minister waived the municipality's obligation to the state by a total amount of CZK 42,785,970. The municipality of Bublava and the company Skanska have been litigating for years (Supreme Audit Office, 2005).

The municipality of Turovice has been dealing with debt issues since 2006 in connection with its investment plan to build a retirement home. The project was supposed to provide 52 apartments with a total number of 80 beds. The municipality had already negotiated and concluded future lease contracts and received a subsidy worth CZK 42 million for the construction from the Ministry of Regional Development. Following a public tender, the municipality commissioned the construction project, worth CZK 45 million, to the company SDK from Lipník nad Bečvou. However, during the course of the project, the company 
required an additional CZK 25 million for its completion. The municipality refused to pay any additional funds to the contractor which, in return, stopped all construction work. Since 2008, the contractor and the municipality have been engaged in lawsuits. Because the project was not completed, the municipality breached budgetary discipline and has been required by the Ministry of Regional Development to return CZK 42 million plus penalties in the same amount. Therefore, the municipality's liabilities shot up by CZK 84 million in 2011 (Ministry of Finance of the Czech Republic, 2010, 2015).

The municipality of Pohled encountered financial problems as early as 2000 in connection with its plan to build a new primary school building. During the years 2000-2001, the municipality received a state subsidy totaling CZK 24,560,000. However, the school was not built, and the municipality needed to return the subsidy owing to its breach of subsidy terms and conditions. In 2004, the municipality was ordered to return the subsidy plus a penalty of CZK 48,960,480. In 2005, the Ministry of Finance approved an application by the municipality's mayor for a waiver of the municipality's obligations to the state. At the end of the same year, the municipality's liabilities amounted to CZK 23,800,000. In 2007, the municipality's payment schedule was approved.

The municipality of Měňany became known mainly thanks to the implementation of an investment project to secure district heating for the entire municipality using biomass. Měnany won the national round of a prestigious global competition known as the Energy Globe Award and ranked among the three best projects worldwide in the "Fire" category. The total investment costs of the project amounted to CZK 48,459,870. The municipality received a subsidy of CZK 17,075,000 from the State Fund of the Environment; the remainder of the project $(65 \%)$ was financed by its own funds, using a long-term loan (Ondráčková, 2009).

Table 5 presents the individual municipalities' liabilities in thousands of CZK for the years 2001-2013. We can see that, at the end of 2013, the liabilities used by the municipality of Prameny escalated to CZK 91,490,000. In 2009, the local municipal council collapsed, and the municipality was governed by an administrator until 2012. During this period, the municipality's liabilities increased by CZK 64,300,520. Recently, 90\% of the obligations were purchased by the company Real Aspekt, which plans to build a mineral water bottling plant in Prameny, i.e., the same project that led the municipality into financial problems.

The municipality of Bublava substantially increased its liabilities in 2003 (CZK 113,594,980) in connection with a violation of budgetary discipline. In 2004, the Ministry of Finance waived some of the obligations the municipality owed to the state. In 2004, the municipality's foreign liabilities began to decrease. However, this trend was interrupted in 2009. The municipality has tried to reduce its liabilities by selling its assets. In 2003, the municipality's assets were worth CZK 162,175,610 compared to CZK 10,145,000 in 2013. A noticeable loss is observed primarily for land holdings and construction works. The company Skanska proposed an out-of-court settlement, which would be to handover the half-built construction project and return CZK 5 million. However, the mayor claims that this offer would not resolve the municipality's problem as it still owes the state subsidies worth CZK 20 million. The municipality wants to enter into negotiations with the state to discuss its debt relief. It would be possible to use the money from Skanska as an installment if the municipality's remaining obligations were waived (Ministry of Finance of the Czech Republic, 2010, 2015). 
Table 5: The Liabilities Used by the Municipalities for 2001-2013 (in CZK thousands)

\begin{tabular}{|c|c|c|c|c|c|}
\hline Year & Prameny & Bublava & Turovice & Pohled & Měnany \\
\hline $\mathbf{2 0 0 1}$ & $30,946.45$ & $1,037.65$ & 39.33 & $1,632.25$ & 21.70 \\
\hline $\mathbf{2 0 0 2}$ & $34,628.01$ & $11,735.00$ & 65.82 & $1,351.35$ & 15.65 \\
\hline $\mathbf{2 0 0 3}$ & $41,897.43$ & $113,594.98$ & 67.10 & 99.37 & 57.11 \\
\hline $\mathbf{2 0 0 4}$ & $42,496.91$ & $58,957.47$ & 69.05 & $49,024.92$ & 43.13 \\
\hline $\mathbf{2 0 0 5}$ & $42,927.28$ & $51,759.57$ & 58.72 & $23,992.43$ & 53.68 \\
\hline $\mathbf{2 0 0 6}$ & $48,898.47$ & $47,942.47$ & 68.80 & $22,794.70$ & $16,752.88$ \\
\hline $\mathbf{2 0 0 7}$ & $49,716.67$ & $43,996.04$ & 61.23 & $21,582.00$ & $19,810.15$ \\
\hline $\mathbf{2 0 0 8}$ & $36,705.00$ & $43,242.16$ & 342.20 & $20,385.79$ & $19,777.93$ \\
\hline $\mathbf{2 0 0 9}$ & $27,189.48$ & $44,948.16$ & $2,778.54$ & $19,188.33$ & $18,498.92$ \\
\hline $\mathbf{2 0 1 0}$ & $93,467.00$ & $38,901.00$ & $2,869.00$ & $18,956.00$ & $18,933.00$ \\
\hline $\mathbf{2 0 1 1}$ & $92,116.00$ & $37,267.00$ & $86,052.00$ & $9,702.00$ & $17,513.00$ \\
\hline $\mathbf{2 0 1 2}$ & $90,767.00$ & $37,336.00$ & $85,947.00$ & $2,052.00$ & $16,880.00$ \\
\hline $\mathbf{2 0 1 3}$ & $91,490.00$ & $38,177.00$ & $85,558.00$ & 293.00 & $16,054.00$ \\
\hline
\end{tabular}

Source: Authors' own calculations based on data of the Ministry of Finance of the Czech Republic: Státní závěrečné účty $2001-2013$ [online] [cit. 15. January 2016]. Accessible at: www.mfcr.cz/cs/vyhledavani?q=st\%C3\%A1tn\%C3\%AD+z\%C3\%A1v\%C4\%9Bre\%C4\%8Dn\%C3\%A9+\%C3 $\% \mathrm{BA} \% \mathrm{C} 4 \% 8 \mathrm{Dty}$ and the Ministry of Finance of the Czech Republic: Zadluženost územních rozpočtů v letech 2014, 2013, 2012, 2011, 2010, 2009, 2008, 2007 [online] [cit. 15. January 2016]. Accessible at: www.mfcr.cz/cs/verejny-sektor/monitoring/zadluzenost-uzemnich-rozpoctu

The liabilities used by the municipality of Turovice rose in 2011 due to a violation of budgetary discipline during the retirement home investment project. Given its rather limited budget, the municipality has not been able to repay its obligations faster. The mayor claims that the municipality spends about CZK 25,000 per month (approx. CZK 300,000 per year) to discharge its debts. At this rate, the municipality will pay off its debts in 276 years.

The municipality of Pohled first faced an increase in liabilities in 2004 due to a violation of budgetary discipline, namely due to its failure to observe subsidy terms and conditions. In 2005 , the amount of liabilities fell by about half, which was due to a waiver of penalties by the Ministry of Finance. Since 2005, the municipality has continued to reduce its liabilities. The largest drop was observed during the years 2010-2012, when the municipality sold a chateau estate together with the half-built school building, vast land holdings, and a number of other buildings to a private company. In 2013, the municipal debts were as low as CZK 293,000 .

Unlike the municipalities mentioned above, Měn̆any is rather unique as it managed to implement its investment project. Its debt consists mainly of a long-term bank loan received in 2006. As shown in Table 5, this municipality has been reducing its obligations since 2006 and has been repaying the loan on time. According to its mayor, the municipality of Měñany repays its loan mainly from heating payments from local customers, as well as partly from the municipal budget. At present, the municipality cannot afford to implement any other projects. However, it does not regret its decision to build a municipal heating system based on biomass. 
Table 6: The Rate of Liabilities to Total Assets (in \%) and the Standard Liquidity of the Municipalities for 2001-2013

\begin{tabular}{|c|c|c|c|c|c|c|c|c|c|c|}
\hline Year & \multicolumn{2}{|c|}{ Prameny } & \multicolumn{2}{|c|}{ Bublava } & \multicolumn{2}{|c|}{ Turovice } & \multicolumn{2}{|c|}{ Pohled } & \multicolumn{2}{|c|}{ Měňany } \\
\hline 2001 & $44.45 \%$ & 0.12 & $1.08 \%$ & 3.30 & $0.32 \%$ & 4.46 & $3.23 \%$ & 2.04 & $0.30 \%$ & 121.88 \\
\hline 2002 & $48.02 \%$ & 0.14 & $9.28 \%$ & 9.43 & $0.59 \%$ & 14.41 & $2.59 \%$ & 2.25 & $0.20 \%$ & 109.77 \\
\hline 2003 & $\mathbf{5 3 . 5 1 \%}$ & 0.15 & $66.26 \%$ & 0.10 & $0.68 \%$ & 21.53 & $0.20 \%$ & 24.88 & $0.65 \%$ & 45.56 \\
\hline 2004 & $57.14 \%$ & 0.21 & $34.70 \%$ & 0.18 & $0.68 \%$ & 20.17 & $83.43 \%$ & 0.07 & $0.48 \%$ & 39.07 \\
\hline 2005 & $\mathbf{5 6 . 5 0} \%$ & 0.23 & $31.07 \%$ & 0.17 & $0.54 \%$ & 31.72 & $39.64 \%$ & 0.18 & $0.45 \%$ & 11.63 \\
\hline 2006 & $64.85 \%$ & 0.19 & $29.03 \%$ & 0.12 & $0.44 \%$ & 16.99 & $35.75 \%$ & 0.21 & $41.73 \%$ & 0.71 \\
\hline 2007 & $65.88 \%$ & 0.19 & $26.51 \%$ & 0.14 & $0.11 \%$ & 14.37 & $32.35 \%$ & 0.30 & $41.90 \%$ & 3.74 \\
\hline 2008 & $52.43 \%$ & 0.26 & $26.05 \%$ & 0.14 & $0.59 \%$ & 1.81 & $29.02 \%$ & 0.41 & $41.52 \%$ & 0.68 \\
\hline 2009 & $64.09 \%$ & 0.35 & $27.26 \%$ & 0.10 & $4.55 \%$ & 0.13 & $26.82 \%$ & 0.44 & $37.75 \%$ & 0.83 \\
\hline 2010 & $293.82 \%$ & 0.29 & $26.64 \%$ & 0.11 & $4.73 \%$ & 0.12 & $26.49 \%$ & 0.46 & $38.25 \%$ & 0.64 \\
\hline 2011 & $594.64 \%$ & 0.18 & $34.42 \%$ & 0.12 & $143.90 \%$ & 0.01 & $25.34 \%$ & 0.54 & $37.88 \%$ & 0.30 \\
\hline 2012 & $517.81 \%$ & 0.32 & $34.49 \%$ & 0.12 & $143.52 \%$ & 0.34 & $6.49 \%$ & 6.20 & $37.29 \%$ & 0.56 \\
\hline 2013 & $487.74 \%$ & 0.41 & $35.06 \%$ & 0.15 & $141.33 \%$ & 0.52 & $0.91 \%$ & 38.06 & $35.26 \%$ & 1.23 \\
\hline
\end{tabular}

Source: Authors' own calculations based on data from the Ministry of Finance of the Czech Republic: Státní závěrečné účty $2001-2013$ [online] [cit. 15. January 2016]. Accessible at: www.mfcr.cz/cs/vyhledavani?q=st\%C3\%A1tn\%C3\%AD+z\%C3\%A1v\%C4\%9Bre\%C4\%8Dn\%C3\%A9+\%C3 $\%$ BA\%C4\%8Dty and the Ministry of Finance of the Czech Republic: Zadluženost územních rozpočtu v letech 2014, 2013, 2012, 2011, 2010, 2009, 2008, 2007 [online] [cit. 15. January 2016]. Accessible at: www.mfcr.cz/cs/verejny-sektor/monitoring/zadluzenost-uzemnich-rozpoctu

Table 6 presents the values of the liabilities-to-total assets indicator (in \%) and the standard liquidity of the selected municipalities for the given period. These indicators are monitored annually by the Ministry of Finance using the Municipal Financial Management Monitoring system. In this monitoring system, the Ministry of Finance requires that the liabilities-to-total assets indicator must be less than or equal to $25 \%$, while the standard liquidity indicator should be within the $\langle 0 ; 1>$ interval. If a municipality exceeds the limits set by the Ministry of Finance in a certain year, the respective number is marked in bold in the table.

\section{Conclusion}

It can be concluded that municipal indebtedness is not significant when compared to the public debt of the Czech Republic. In recent years, municipal indebtedness has ranged between CZK 80 and 90 billion. Close attention should be paid to the indebtedness of small municipalities rather than to total debt and its structure. Because the Czech Republic does not have legislation regulating the tools used to resolve municipal over-indebtedness, the municipalities that are currently confronted with excessive debt (see the municipalities of Prameny, Bublava, or Turovice) are not capable of resolving - or at least partially eliminating - their problems. Indebtedness issues are not specifically regulated in the Czech Republic. There are only certain tools that can prevent or partially regulate municipal indebtedness.

The analysis conducted here suggests that municipalities encounter financial trouble mainly in connection with investment projects that are not implemented. Nowadays, municipal debt can be amortized by sales of its assets or by forced execution (e.g., the municipality of Prameny lost its local government agency building). By way of conclusion, it can be stated that municipal indebtedness as a whole is not very high (its percentage of public debt was $5.01 \%$ in 2013). The four largest Czech cities are major contributors to total indebtedness. In 2013, their debts represented $53.40 \%$ of total municipal indebtedness.

Current legislation stipulates only preventive measures that attempt to avoid municipal indebtedness or partially regulate it. However, these rules are not sufficient to prevent situations in which a municipality is able to accumulate excessive debt (i.e., it is not capable 
of paying its obligations and the very operation of the municipality is at risk). Czech legislation does not provide any regulation that would allow for debt relief to municipalities.

Unlike Germany and France, the Czech Republic does not have an institution to deal with analyzing municipal debt, credit risk, and credit rating and subsequently monitoring municipal debt. If an institution were established, it could prevent municipal debt, regulate it, or provide loans to municipalities under more favorable conditions than those on the capital market. As a community of citizens, municipalities have the right to their own selfgovernment as established in the Constitution; the state is allowed to intervene in their activities in cases where the protection of the law is required. The question thus arises, to what extent should the state be able to control their debt? Financial problems related to municipal indebtedness is not in the interest of the municipality's citizens. Therefore, excessive debt can be considered contrary to the interests of the municipality's citizens; consequently, the state has the option to regulate the situation.

The authors of this paper see inspiration in Slovak legislation, which regulates the situation of municipal over-indebtedness Slovak municipalities do not use repayable resources to finance the deficit of the current budget. These can be used only if there is a discrepancy in timing between revenues and expenditures in the current budget and if accounts are paid by the end of the financial year. The authors also argue that the current system of the municipal administrator should be modified, because current legislation does not allow the administrators to help municipalities with their problem. The municipality of Prameny's debts increased in the years they were under the administration of the Ministry of Interior for precisely this reason. The administrator paid only the necessary expenses and, for example, was not able to negotiate with the creditors. The authors would again use the example of the Slovak law concerning municipal administrators who oversee municipal over-indebtedness and a so-called "curative regime and forced administration."

The issue of indebtedness (or over-indebtedness) is being faced by several small municipalities in the Czech Republic. Large cities are capable of fulfilling their obligations. Nonetheless, the state should pass legislation to regulate situations in which a municipality is no longer able to meet its obligations.

\section{Acknowledgement}

This contribution was supported by the SGSFES_2015003 fund.

\section{References}

[1] ANG, A. et al., 2013. Advance Refundings of Municipal Bonds. NBER Working Paper, No. 19459, 59. Cambridge: National Bureau of Economic research. Without ISBN.

[2] CZECH STATISTICAL OFFICE, 2015. Ekonomické subjekty podle právní formy [online]. [cit. 27. January 2016]. Accessible at: vdb.czso.cz/vdbvo/tabparam.jsp? page $=$ strom $\&$ vo=tabulka\&cislotab=ORG9020UC\&voa=tabulka\&go_zobraz=1\&childsel $0=5$

[3] CZECH STATISTICAL OFFICE, 2015. Dluh sektoru vládních institucí [online]. [cit. 27. January 2016]. Accessible at: apl.czso.cz/pll/rocenka/rocenkavyber.gov_d

[4] DAFFLON, B., 2002. Local public finance in Europe: balancing the budget and controlling debt. Northampton, MA: Edward Elgar. ISBN 18-406-4878-3.

[5] DVOŘÁK, P., 2008. Veřejné finance, fiskální nerovnováha a finanční krize. Vyd. 1. Praha: C. H. Beck. ISBN 978-80-7400-075-1. 
[6] KAMENÍČKOVÁ, V., 2014. Je přebytek rozpočtu obce skutečně vždy žádoucí? Moderni obec, XX(9), 11. Praha: Profi Press s. r. o. ISSN 1211-0507.

[7] KAMENÍČKOVÁ, V., 2011. Saldo a dluh obcí podle velikostních skupin. Obec \& finance: odborné periodikum pro ekonomické otázky obci a měst, XVI(5), 29. Praha: Triada. ISSN 1211-4189.

[8] MINISTRY OF FINANCE OF THE CZECH REPUBLIC, 2010. ARISweb [online]. [cit. 15. January 2016]. Accessible at: www.mfcr.cz/cs/o-ministerstvu/zakladniinformace/informacni-systemy/arisweb

[9] MINISTRY OF FINANCE OF THE CZECH REPUBLIC, 2015. MONITOR [online]. [cit. 27. January 2016]. Accessible at: www.mfcr.cz/cs/o-ministerstvu/zakladniinformace/informacni-systemy/arisweb

[10] MINISTRY OF FINANCE OF THE CZECH REPUBLIC, 2008. Monitoring hospodařeni obci [online]. [cit. 27. January 2016]. Accessible at: www.mfcr.cz/cs/verejny-sektor/regulace/hospodareni-kraju-a-obci/monitoringhospodareni-obci

[11] MINISTRY OF FINANCE OF THE CZECH REPUBLIC, 2013. Státní závěrečné účty $2001-2013$ [online]. [cit. 27. January 2016]. Accessible at: www.mfcr.cz/cs/vyhledavani?q=st\%C3\%A1tn\%C3\%AD+z\%C3\%A1v\%C4\%9Bre\%C4 $\% 8 \mathrm{Dn} \% \mathrm{C} 3 \% \mathrm{~A} 9+\% \mathrm{C} 3 \% \mathrm{BA} \% \mathrm{C} 4 \% 8 \mathrm{Dty}$

[12] MINISTRY OF FINANCE OF THE CZECH REPUBLIC, 2014. Zadluženost územních rozpočti̊ v letech 2014, 2013, 2012, 2011, 2010, 2009, 2008, 2007 [online]. [cit. 27. January 2016]. Accessible at: www.mfcr.cz/cs/verejny-sektor/monitoring/zadluzenostuzemnich-rozpoctu

[13] ONDRÁČKOVÁ, J., 2009. Biomasa jako zdroj tepla. Moderní obec [online]. [cit. 27. January 2016]. Accessible at: moderniobec.cz/biomasa-jako-zdroj-tepla/

[14] PEKOVÁ, J., 2011. Finance územní samosprávy: teorie a praxe $v \check{C} R$. Praha: Wolters Kluwer Česká republika. ISBN 978-807-3576-141.

[15] PROVAZNÍKOVÁ, R., 2009. Financování měst, obci a regionü: teorie a praxe. $2^{\text {nd }}$ ed. Praha: Grada. ISBN 978-80-247-2789-9.

[16] SEDMIHRADSKÁ, L., 2015. Municipal finance and budgeting in the Czech Republic [online]. [cit. 28. January 2016]. Accessible at: www.researchgate.net/ profile/Lucie_Sedmihradska/publication/233560627_Municipal_finance_and_budgeting _in_the_Czech_Republic/links/0912f50ab8427b204d000000.pdf

[17] SUPREME AUDIT OFFICE, 2005. Financování výstavby víceúčelového zařízení v obci Bublava. Věstník NKÚ [online]. [cit. 28. January 2016]. Accessible at: www.nku.cz/scripts/detail.php?id=898

[18] UNION OF TOWNS AND MUNICIPALITIES OF THE CZECH REPUBLIC, 2014. Tiskový servis [online]. [cit. 29. January 2016]. Accessible at: www.smocr.cz/cz/tiskovyservis/informovali-o-nas/ceska-televize-zadluzene-prameny.aspx 